\title{
Antibodies and their receptors: different potential roles in mucosal defense
}

\author{
Rachel E. Horton ${ }^{1}$ and Gestur Vidarsson ${ }^{2}$ * \\ 1 Institute for Glycomics, Griffith University, Gold Coast, QLD, Australia \\ ${ }^{2}$ Department of Experimental Immunohematology, Sanquin Research and Landsteiner Laboratory, Academic Medical Center, University of Amsterdam, \\ Amsterdam, Netherlands
}

\section{Edited by:}

Ed C. Lavelle, Trinity College Dublin, Ireland

\section{Reviewed by:}

Jiri Mestecky, University of Alabama

at Birmingham, USA

Per Brandtzaeg, Oslo University

Hospital, Norway

\section{${ }^{*}$ Correspondence}

Gestur Vidarsson, Sanquin Research and Landsteiner Laboratory,

Academic Medical Center, University of Amsterdam, Plesmanlaan 125

1066 CX Amsterdam, Netherlands

e-mail: g.vidarsson@sanquin.nl
Over recent years it has become increasingly apparent that mucosal antibodies are not only restricted to the $\lg \mathrm{M}$ and $\lg \mathrm{A}$ isotypes, but that also other isotypes and particularly IgG can be found in significant quantities at some mucosal surfaces, such as in the genital tract. Their role is more complex than traditionally believed with, among other things, the discovery of novel function of mucosal immunoglobulin receptors. A thorough knowledge in the source and function and mucosal immunoglobulins is particularly important in development of vaccines providing mucosal immunity, and also in the current climate of microbicide development, to combat major world health issues such as HIV. We present here a comprehensive review of human antibody mediated mucosal immunity.

Keywords: antibody, mucosal, $\lg A, \lg G, \lg D, \lg M$

\section{INTRODUCTION}

Mucosal surfaces are the primary point of contact for numerous infectious agents including the world's three major causes of mortality due to infectious disease, diarrheal diseases, lower respiratory tract infections, and HIV/AIDS. According to WHO statistics, together these account for $27.3 \%$ of global deaths. In addition to defending from infection, the mucosal immune system must be able to discriminate between pathogens and foreign proteins derived from ingested material in order to prevent potentially harmful responses to innocuous antigens.

Initial defense occurs through indiscriminate mechanical action, mucus, cilia, and the epithelial cell barrier, for example. The epithelial cells themselves provide these surfaces with bactericidal proteins and antimicrobial peptides (1) and take a large part in generating the cytokine milieu required for the adaptive immune response, and probably participate directly in the initiation and eradication of infection as discussed below. More specialized action is directed and regulated by surveillant myeloid phagocytes and the other cells of the mucosal immune system, located in local lymphoid compartments which make up the mucosa-associated lymphoid tissue (MALT) as well as in the lamina propria. Cellular immunity has a clear role in induction and coordination of the adaptive immune response at mucosal surfaces [reviewed in (2)] but here we concentrate on the contribution of the end product of the humoral immune response. This is characterized by secretory IgA (SIgA) that is present at higher levels at mucosal sites than other immunoglobulins, notable exceptions to this rule being the female and male genital tract (3-5), bronchoalveolar fluid, and bile (6) where IgG is dominant. Although present at lower levels in external secretions [levels of all immunoglobulins in mucosal secretions are reviewed by Norderhaug et al. and Mestecky et al. $(5,7)]$, IgM also has a role in mucosal defense and it has recently been noted that IgD may play an important part (8).

It has been observed that macromolecules derived from plasma can exude to the mucosal surface by bulk flow through epithelial tight junctions that can filter these molecules depending on size $(\sim 7-15 \AA)$ and sub-epithelial hydrostatic pressure $(9,10)$. However, the different immunoglobulin isotypes ( $\operatorname{IgG} \sim 55 \AA$ ), are bigger than most of these tight junctions to allow for free passage. They do however interact with novel immunoglobulin receptor systems that mediate their functions via passive transfer, active destruction through phagocytosis, or antigen sampling and presentation for enhanced immune responses. Collectively, these functions are crucial for the interplay between the innate and adaptive immune systems. Current knowledge in this area together with latest findings on how subversive pathogens evade these mechanisms are reviewed below.

\section{SOURCES AND PASSIVE FUNCTION OF MUCOSAL IMMUNOGLOBULINS \\ IMMUNOGLOBULIN A}

The mucosal environment is programed to induce B cell class switching to IgA production as both mucosal $\mathrm{T}$ cells and mucosal epithelial cells themselves produce TGF- $\beta$ and IL-10, cytokines essential for programing of committed IgA producing B cells (11). Although, systemic IgA responses tend to occur in germinal center reactions, and require $\mathrm{T}$ cells, a significant portion of the $\operatorname{IgA}$ response $\left(\mathrm{CD}^{2} 7^{-} \mathrm{IgA}{ }^{+}\right)$does not require $\mathrm{T}$ cells, as they harbor low frequency of somatic hypermutations and develop normally in both mouse and humans lacking either CD40 or CD40L, respectively $(12,13)$. In the gut, this $\mathrm{T}$ cell independent mechanism preferentially leads to class switching to IgA 2 with $\lambda$-light chains $(13,14)$. The reason for the selective usage of the $\lambda$-locus for 
the light chains is unknown, but may reflect the selection for binding to unknown human pathogens - a feature also found for IgD responses in tonsils (8). Although serum IgA is mainly monomeric, originating from the bone marrow, but also lymph nodes and spleen, at mucosal surfaces it is usually polymeric, synthesized locally by plasma cells located in the lamina propria (15).
These polymers, most often dimers, linked by the cysteine rich J chain, are secreted across the mucosal epithelium via the polymeric immunoglobulin receptor ( $\mathrm{pIgR}$, also termed membrane secretory component, SC). Post transcytosis protease cleavage releases IgA complexed with the extracellular part of the pIgR (bound SC), as SIgA into the mucosal lumen (Figure 1A). SIgA has traditionally
A

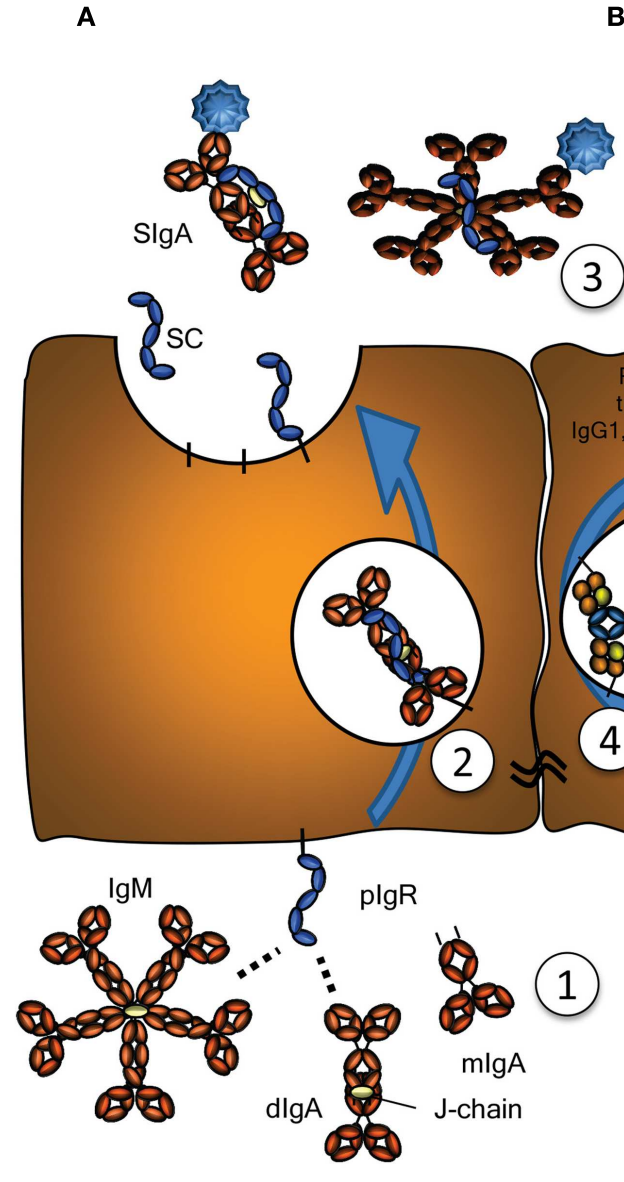

FIGURE 1 | Transport of Immunoglobulins to mucosal surfaces. Mucosal IgA, IgM, produced locally at the lamina propria, and IgG, produced either locally or systemically, are transported by (A) the Polymeric Immunoglobulin Receptor (plgR) or (B) by the Neonatal Fc-Receptor (FcRn), respectively. (A) The plgR, expressed on serous-type secretory epithelial cells, specifically binds $\mathrm{J}$ chain containing dimers (and larger polymers) of IgA or pentamers of $\lg \mathrm{M}$ at basolateral surfaces, but not serum-derived monomeric $\lg \mathrm{A}$ (1). This prompts uptake and transport through the cell (2), eventually resulting in subsequent vesicle fusion at apical sites where the plgR is cleaved, releasing the extracellular domain of plgR either as free SC (unoccupied) or bound SC in SlgA and SIgM (3). SC remains bound to the $\lg A$ and $\lg M$, for IgA covalently, blocking its interaction with the $\mathrm{F} c \alpha \mathrm{RI}$, but can also be released from IgM upon purification. (B) Mucosal transport of IgG is initiated by pinocytosis and/or receptor mediated uptake of IgG. During the initial stages of IgG-transport, the $\mathrm{pH}$ is probably neutral, under conditions where FcRn has no or negligible affinity for IgG (1). After acidification of the developing vacuoles and fusion with FcRn-containing vesicles or tubules, changes in the charge of the IgG-Fc tail induce the recognition of $\lg G$ by $F_{c} R n$, where a single $\lg \mathrm{G}$ is probably recognized by two $\mathrm{FcRn}$ molecules on parallel membranes (4). This induces the rescue of this IgG from lysosomal degradation and transcytosis to the apical surface, where the cargo is released at physiological $\mathrm{pH}$ (3). The relative transport rate for the $\lg \mathrm{G}$ subclasses is similar to what is seen for their FcRn-mediated half-life, with few exceptions, as discussed in the text, and likely to be allotype dependent for lgG3 (indicated with an asterix). Interaction of opsonized pathogens or immune complexes may also cause local complement activation, eventually leading to target lysis and/or opsonization, but also release of $\mathrm{C} 5 \mathrm{a}$, a powerful anaphylatoxin and a chemo attractant. Interaction with myeloid Fc $\gamma R$ and Fc $\alpha$ R also leads to degranulation and release of chemotactic factors, thereby inducing enhanced migration of lymphoid and myeloid cells to the inflamed site, here depicted above the surface, but in real life probably scavenging the surface by close adherence (5), eventual clearance of the infection and resolution of inflammation. As discussed in the text, these immunoglobulin transport pathways may also neutralize pathogens localized either at the basolateral side or within intracellular vacuoles allowing for their intracellular degradation or expulsion. Also discussed in the text, is the possible involvement of the cytoplasmic Ig-receptor TRIM21 for intracellular degradation of opsonized non-enveloped viruses and intracellular bacteria. 
been perceived as an anti-inflammatory mediator (16) with three major functions: (1) to physically block pathogen attachment and invasion (immune exclusion), (2) to recognize foreign antigens and escort them through epithelial cells ridding the mucosa of excess antigens, and (3) to intercept viruses intracellularly (during transcytosis), thereby facilitating their neutralization and expulsion already within infected cells (17). This latter mechanism was suggested and experimentally confirmed in the early 90s and has been reconfirmed for the measles virus $(17,18)$. Further support for this view of SIgA as a non-inflammatory antibody comes from its poor ability to activate the classical complement pathway; it lacks the C1q binding motif found in IgG. Although it has been shown to activate complement through the lectin pathway, this is probably dependent on the glycosylation status of in the IgA1 (19). IgA1 glycosylation has recently been shown to be highly complex, with several glycosylation isomers $(20,21)$, suggesting that IgAfunction may also be modulated though glycosylation in a similar manner as recently described for IgG as discussed below (22). Surprisingly, glycosylation of the IgA-bound SC has also been reported to affect binding of IgA to commensal bacteria (23). Importantly, IgA can also actively mediate protection against invasive disease, because, in addition to transport of secretory immunoglobulins, the pIgR is able to transport immune complexes across polarized cell lines in vitro, releasing them at the apical surface, hence suggesting a direct role for the $\mathrm{pIgR}$ and IgA in clearance of pathogens from the sub-epithelial mucosa (24).

\section{IMMUNOGLOBULIN M}

IgM is the first immunoglobulin to appear during an infection and is found at detectable albeit low levels in secretions. The largest of the antibodies, it occurs as a pentamer and is transported across epithelial cells in the same way as IgA, via its J chain and the pIgR (Figure 1A) (25). There are fewer IgM than IgA secreting cells at mucosal surfaces, and its net-mucosal transfer is mediated less efficiently than that of IgA (25). As pIgR-mediated epithelial transport of both isotypes occurs at equal rates in vitro (5), the reason for the lower transport is probably due to its large size and therefore less efficient diffusion through epithelial basement membranes, resulting in a lower mucosal concentration than what could be predicted from the local production of IgM. Despite these low mucosal levels, it does show elevated levels in individuals with IgA deficiency, in a compensatory manner, and provides some protection from infection. Although it hardly activates myeloid cells, mediating effector functions primarily through complement, a potential role has recently been described for the myeloid IgM receptor, TOSO (26). Mice lacking this receptor show elevated Reactive Oxygen Species (ROS) production after formyl-Methionyl-Leucyl-Phenylalanine (fMLP) stimulation, but reduced IgM-mediated phagocytosis, reduced inflammatory cytokine production after challenge with Listeria monocytogenes, ultimately leading $\mathrm{TOSO}^{-1-}$ mice to succumb faster to Listeria infection (27). The role of this receptor in humans for IgM-mediated antimicrobial defense remains to be elucidated.

\section{IMMUNOGLOBULIN D}

Monomeric IgD forms the major part of the $\mathrm{B}$ cell receptor and is therefore present in membrane bound form on naïve and memory
$\operatorname{IgM}^{+} \operatorname{IgD}^{+} \mathrm{B}$ cells and also on class switched $\operatorname{IgM}^{-} \operatorname{IgD}^{+}$memory B lymphocytes (8). IgD secreting plasmablasts are scarce in bone marrow and the digestive system (28), but are found at higher frequencies in the lacrimal gland, nasal mucosa, and tonsils (29), with as many as $20-25 \%$ of plasmablasts/plasma cells producing IgD being reported for the tonsils (8). The number of these cells has however been disputed, and may be on average be below 5\% (30). Research concerning the function of IgD has lagged behind that of other immunoglobulins, due in part to methodological difficulties in detection, its low concentration in serum, and its absence in a number of animal systems including rabbit and guinea pig (31). However, human IgD class switched B cells, most of which also express the $\lambda$-light chains as discussed above for IgA, have recently been identified and shown to secrete both mono- and poly-reactive antibodies which react with respiratory pathogens including Haemophilus influenzae. It has been hypothesized to be part of an evolutionarily conserved immune surveillance system activating effector functions of basophils (8). Many questions regarding the function of $\operatorname{IgD}$, including how $\operatorname{IgD}$ finds its way into secretions - which may occur by either receptor- or nonreceptor mediated mechanisms, remain unanswered [reviewed in (32)], and await confirmation.

\section{IMMUNOGLOBULIN G}

The presence of IgG in external secretions has largely been ignored in the literature, but recent work has demonstrated that this isotype is capable of mediating active humoral protection in various mucosal locations (33-36). Human IgG consist of four subclasses, $\operatorname{IgG} 1, \operatorname{IgG} 2, \operatorname{IgG} 3$, and $\operatorname{IgG} 4$, with reference to their decreasing abundance in serum. They all have remarkably different effector functions, with respect to both complement activation and binding to $\mathrm{Fc} \gamma \mathrm{R}$ (as discussed in a more detail below), with the general order of activating capacity for both being $\operatorname{IgG} 3>\operatorname{IgG} 1>>\operatorname{IgG} 2>\operatorname{IgG} 4$. IgG is present at significant levels at all mucosal surfaces, and although IgA is the most abundant mucosal antibody, IgG concentrations actually exceed those of IgA at a number of locations, including the male and female genital tracts and bronchoalveolar fluids, where it is the predominant antibody isotype $(3,4)$. Mucosal IgG is believed to be produced locally as IgG producing plasma cells are certainly found locally in the genital tracts of both sexes, but can also transudate from serum - the level of which is under regulation by hormonal- and menstrualcycle in females $(4,37)$. Regardless of the source, IgG is probably transported through all epithelial layers, under conditions when the epithelial layer is intact with low sub-epithelial pressure, by the neonatal Fc-receptor (FcRn), a MHC class I homolog (Figure 1B). Parenteral administration of passive neutralizing IgG has been shown to prevent oral rotavirus (36), oral and vaginal HIV-1 transmission (34), and lung infection by Streptococcus pneumoniae (35). The mechanisms of this protection may be different depending on the site of action, but have been proposed to occur in secondary lymphoid tissues, mediated by active phagocytosis. Pathogen clearance may also involve complement (35) and it is possible that strong activation of complement by IgG could cause inflammation and damage to the epithelial barrier. Cross-linking of Fc $\gamma$ receptors also triggers a range of other effector functions including phagocytosis, respiratory burst, and Antibody Dependent Cell-mediated 
Cytotoxicity (ADCC) processes that release inflammatory mediators and may also cause damage to epithelial barriers in chronic inflammation [reviewed in (38)]. The activity of the IgG response, can be modified through addition and removal of glycan-moieties at Asn297 in the Fc-portion [reviewed in (39)]. In particular corefucosylation, normally present is serum of $>90 \%$ of all IgG, affects the binding of all IgG subclasses to Fc $\gamma$ RIIIa/b up to several orders of magnitude with accompanying increases in cellular responses (40). Importantly, this type of glycosylation can be regulated at the level of the B cells in humans, as it can be found in certain responses, e.g., anti-platelet responses seen in pregnancy (22). A role for this type of regulation during mucosal immune responses still needs to be investigated.

IgG subclass levels found at mucosal sites, with relative low IgG3 concentrations compared to plasma, correspond what is known about half-life extension (long half-life of IgG1, IgG2, and IgG4, but short half-life of IgG3) and transport though the placenta (no active transport of IgA, but active transport of all IgG, of which transport of IgG1, and IgG4 exceed that of the mother, but with low transport of IgG3 and IgG2), both roles carried out by the FcRn $(41,42)$. Mucosal transport of IgG subclasses therefore correlates with their known half-life and placental-transport properties, suggesting IgG to be actively transported across these mucosal surfaces by FcRn. For example, mucosal transport of IgG3, the only IgG subclass with a half-life of only 1 week (compared to 3 weeks for the other subclasses) seems invariably lower than for the other subclasses (43). A potential concern is that it has been proposed that the long hinge of IgG3 may be more susceptible for proteolytic cleavage (33), but given that this effect is found, for example, in seminal secretion and in saliva, which are quickly expelled, this seems less likely (43). Transport of IgG2, with the exception of salivary transport, seems to be reduced, mirroring what is seen for placental-transport - where both IgG2 and IgG3 are transported to a lesser degree than IgG1 and IgG4 (44). Although mucosal transport of IgG3 was much reduced compared to the other subclasses in the above mentioned study and others (43), we recently found IgG3 is never the less very efficacious in protecting against lung infection by $S$. pneumoniae (33). More importantly, the relative abundance of mucosal IgG3 may also be increased in individuals expressing the $\mathrm{G} 3 \mathrm{~m}(\mathrm{~s}, \mathrm{t})$ allotype of $\operatorname{IgG} 3$ (common in Asians). This is because, unlike the G3m(b) or ( $g$ ) allotypes (common in Europeans) with an arginine at position 435, the G3m(s,t) allotype contains an histidine at this position. This results not only in improved $\mathrm{pH}$-dependent binding to FcRn and prolonged half-life, but also increased placental-transport, suggesting mucosal transport of this IgG3 allotype to be increased as well $(33,41)$. As such, this allotype of IgG3 with both prolonged half-life and even stronger effector functions than all the other IgG subclasses (both in terms of complement activation and binding to $\mathrm{Fc} \gamma \mathrm{R}$ ), may prove important in both health and inflammatory diseases at the mucosa.

\section{RECEPTORS AND ADAPTIVE IMMUNITY}

There are two main, and subsequently well characterized IgA receptors, the pIgR and Fc $\alpha$ RI. Several other receptors have also been reported to bind IgA with, as yet, unclear or uncharacterized functions. The receptors for IgG can be classified into the well-known Fc $\gamma$ R family, consisting of several proteins expressed on myeloid cells, and the FcRn that is ubiquitously expressed at various levels in different cells. These and other less characterized immunoglobulin receptors are summarized in Table 1 and discussed below.

\section{POLYMERIC IMMUNOGLOBULIN RECEPTOR}

The pIgR is responsible for the transport of both SIgA and IgM from the basolateral to the apical epithelial surface at the mucosa (Figure 1A). Irrespective of being bound by IgA or IgM, upon the arrival of the pIgR at the apical surface, the extracellular SC domain is cleaved and the remaining receptor degraded. The SC remains attached to IgA and IgM, but for IgA the linkage is more stable as it is covalent (45). Therefore free, soluble SC can be found at the mucosal surface and each pIgR molecule can only mediate one cycle of transport (46). As discussed below, the pIgR may also recycle without cargo and without cleavage of the SC. Upregulation of pIgR synthesis is mediated by several cytokines including IFN $\gamma$, IL- 1 , and TGF- $\beta$, resulting in increased transport of IgA across the epithelial layer $(47,48)$. Recently, secretion of IL-17 from Th17 cells was suggested to not only stimulate homing of $\mathrm{B}$ cells to the lungs but also to upregulate pIgR expression and enhanced secretion of IgA and IgM, a pathway which is usually held in check by antigen-specific by regulatory T cells (49). Thus, under inflammatory situations or general immunological imbalance, the resulting Th17 like conditions may stimulate mucosal IgA and IgM production and secretion, and intensify the response.

\section{Fc $\alpha \mathbf{R I}$}

The other major IgA receptor is the Fc $\alpha$ RI which is found constitutively on cells of myeloid lineage although expression levels are affected by cytokines and vary with cell type (50). The FcoRI is found in association with the common $\mathrm{FcR} \gamma$-signaling chain (also found associated with $\mathrm{Fc} \gamma \mathrm{R}$ ) which has a cytoplasmic immunoreceptor tyrosine-based activation motif (ITAM) (51). The FcR $\gamma$-chain is responsible for initiation of intracellular events and effector functions, including inflammatory responses against IgA opsonized pathogens. Fc $\alpha$ RI activation status can be modulated through protein phosphatase 2 (PP2A) dependent inside-out signaling, whereby proximal inflammatory mediators may determine whether or how FcaRI is spatially integrated into the lipid membrane and therefore if $F c \alpha R I$ is capable of interacting strongly with IgA to activate cellular responses (Figure 2A) (52). In contrast to serum-derived monomeric IgA (mIgA), which can mediate a number of inflammatory effector functions through the $\mathrm{F} \alpha \mathrm{RI}$ including endocytosis, phagocytosis, a particularly strong respiratory burst, and $\operatorname{ADCC}(50,53,54), \operatorname{SIgA}$ is unable to interact with FcaRI. This interaction with the Fc $\alpha \mathrm{RI}$ is blocked by steric hindrance of the bound SC, contributing to the anti-inflammatory role of IgA at mucosal surfaces where SIgA accounts for the majority of IgA present $(50,53-55)$.

\section{Fc $\gamma R$}

The major IgG receptors, $\mathrm{Fc} \gamma \mathrm{Rs}$, are represented by three different classes found on cells of myeloid origin. They activate myeloid cells through the same ITAM-dependent FcR $\gamma$-signaling chain (except for Fc $\gamma$ RIIa and Fc $\gamma$ RIIc that have their own cytoplasmic ITAM-motives, and Fc $\gamma$ RIIb with an immunoreceptor tyrosinebased inhibitory motif, ITIM) upon receptor crosslinking. This 
Table 1 | Immunoglobulin receptors involved in transport and/or functions of effector cells or molecules at epithelial surfaces.

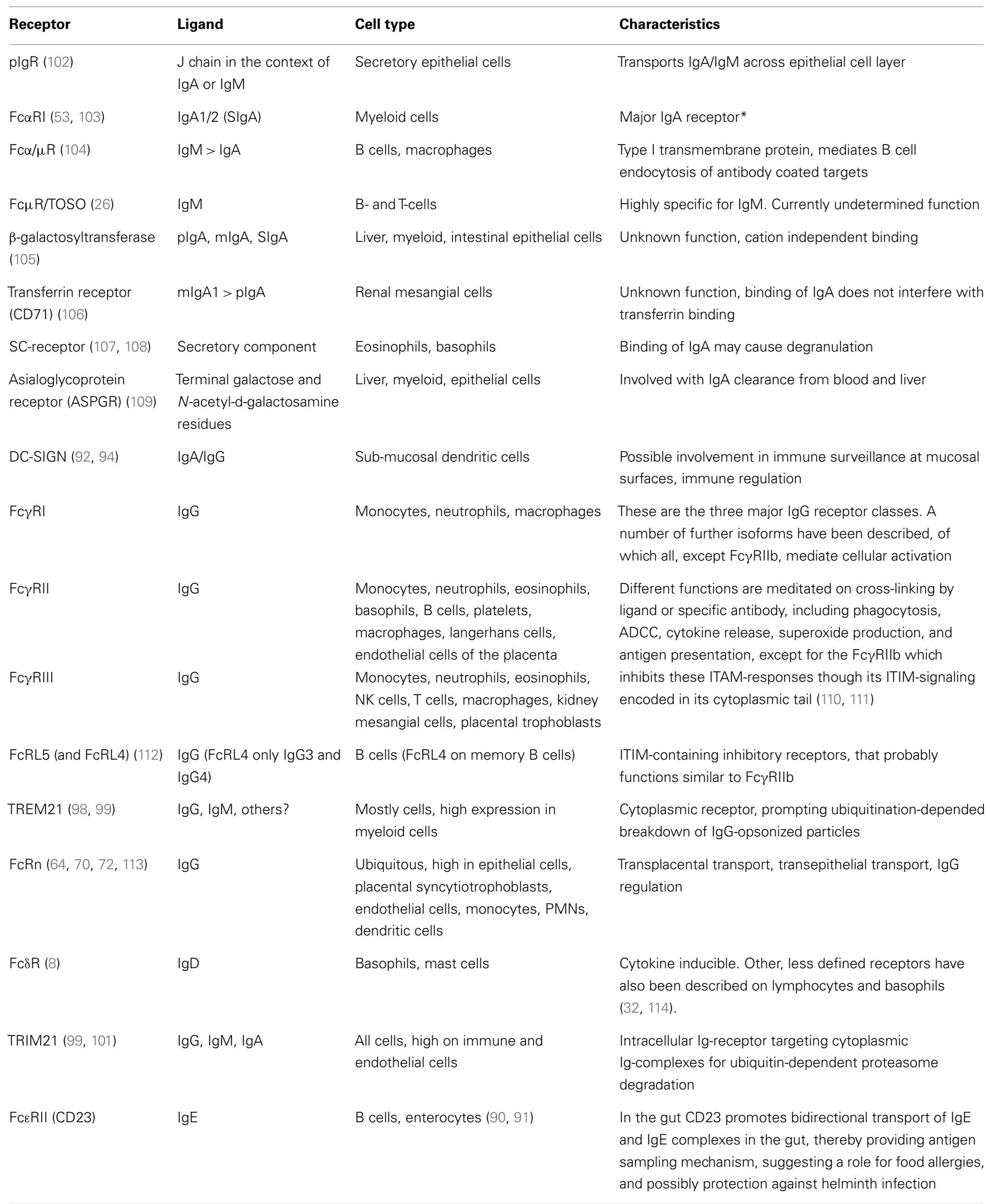

*A number of even less established receptors for IgA on mesangial-, M-, epithelial-, and T-cells have also been reported. 

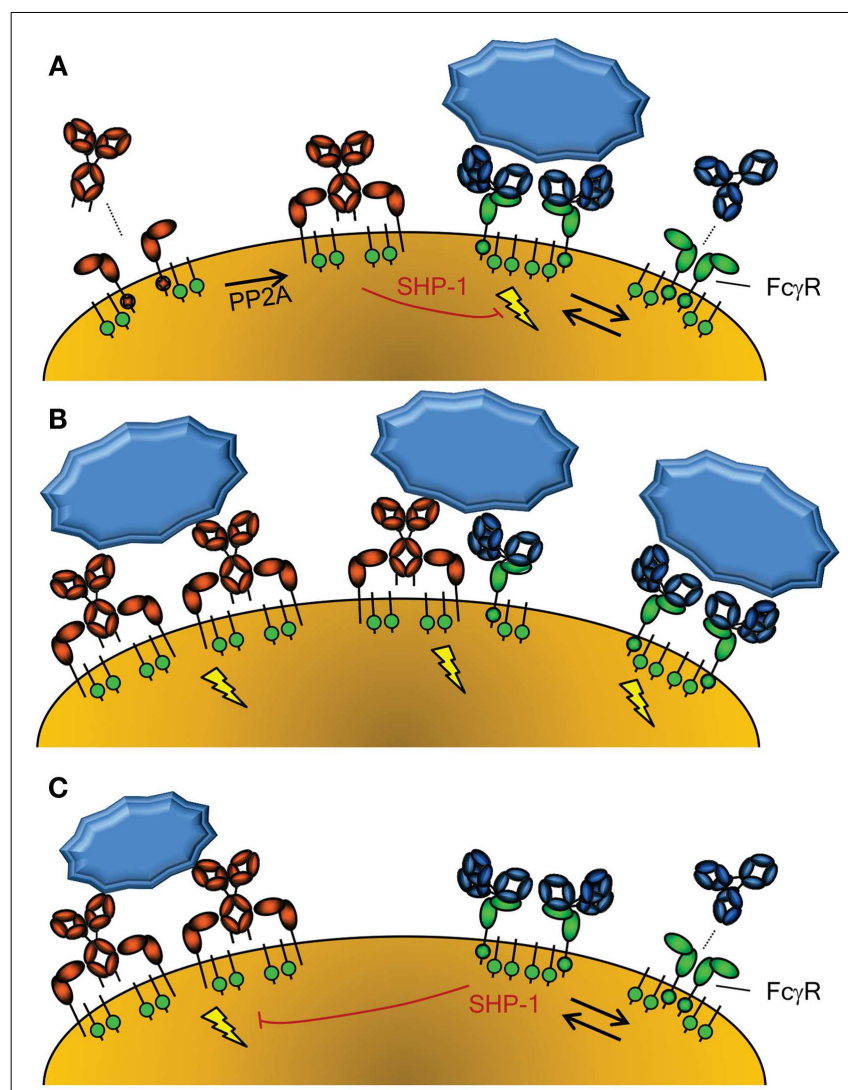

FIGURE 2 | Activation of cellular responses through Fc-Receptors. (A) The activity of $\mathrm{Fc} \alpha \mathrm{RI}$ (left) is controlled through inside-out signaling through PP2A, that dephosphorylates the intracellular tail of FcaRI, enabling binding of IgA (58). Conversely, Fc $\gamma R$ (right) seem to be continuously enabled, although crystallographic data suggest a dimeric form may exist that cannot interact with IgG without disrupting the inert FcyRlla dimer (115). The FcyRlla engaged by IgG may however form a higher order dimer, or multimer, with either another FcyR-IgG unit or unligated Fc $\gamma$ R, forming an active signaling complex after engagement with IgG-opsonized target. However, without crosslinking of FcaRI through IgA and it's cognate antigen, the FcaRl has been reported to lead to down regulation of FcyRl signaling through phosphorylated SYK (58). (B) Importantly, co-engagement of $F c \gamma R$ and $F c \alpha R$ results in a strong activation of phagocyte responses, with $\mathrm{Fc} \alpha \mathrm{Rl}$ leading to a more prominent respiratory burst activation, while Fc $\gamma R$ result more a prominent phagocytosis response (54). (C) Fc $\gamma R$ can also mediate inhibitory signal, because IgG-ligated, either by monomers at high concentrations, dimers, or $\left.\mathrm{F}(\mathrm{ab})_{2}\right)_{2}$-anti Fc $\gamma \mathrm{R}$, can also cause inhibition of other ITAM-, but also non-ITAM, depended cellular activation, also through phosphorylated SYK (60).

results in similar effector functions as seen for the FcoRI that can be down modulated through a negative feedback loop via the inhibiting FcyRIIb [extensively reviewed elsewhere (56)] (Table 1). The binding affinity to each of the Fc $\gamma \mathrm{R}$ differs markedly between different IgG subclasses, the general consensus being IgG3 $\geq$ IgG1 > IgG2 > IgG4, with few exceptions depending on the $\mathrm{Fc} \gamma \mathrm{R}$. The most important exceptions from the rule are that IgG2 only binds Fc $\gamma$ RIIa, and preferentially the H131-Fc $\gamma$ RIIa allotype (also known as the low-responder form, based on its low binding to mouse IgG1) and IgG4 binding Fc $\gamma$ RI with considerable high affinity. Remarkably, the affinity of the IgG subclasses are not directly related with binding of myeloid cells to opsonized targets, as IgG3 seems to surpass all other subclasses in this respect for all Fc $\gamma$ Rs, with few exceptions (57).

\section{CROSSTALK BETWEEN ACTIVATING FCR FAMILIES}

In the absence of specific antigen recognized by $\mathrm{mIgA}, \mathrm{mIgA}$ is also able to mediate anti-inflammatory functions by interacting with $\mathrm{F} c \alpha \mathrm{RI}$ at a low level in a monovalent fashion (without crosslinking FcoRI) and impeding ITAM-initiated signaling of Fc $\gamma$ R, by recruitment and phosphorylation of SHP-1, probably through the low level activation of SYK $(58,59)$ (Figure $2 A$ ). In contrast, serum IgA invokes a massive activation of the myeloid system when opsonized antigen-specific IgA is present (50, 53, 54) (Figure 2B). Thus IgA has several roles; while SIgA is generally anti-inflammatory, mIgA, through Fc $\alpha$ RI, can either mediate massive activation of the myeloid system (Figure $2 \mathrm{~B}$ ) or be immunomodulatory (Figure 2A), depending on the presence or absence of its cognate antigen.

Similar to the Fc $\alpha$ R, Fc $\gamma$ R, human Fc $\gamma$ RIIIa can mediate inhibitory responses of other cellular activation responses, including fMLP, uptake endocytosis through the MARCO scavenging receptor, but also other ITAM bearing receptor, like FceRI (60) (Figure 2C). A similar mechanism has been demonstrated in mice for mouse Fc $\gamma$ RIII (61). This inhibition also involves recruitment of SHP-1, and its phosphorylation, probably through SYK. This inhibition, both for Fc $\gamma$ R and FcaRI, therefore seems to be a general phenomenon of ITAM mediated signaling, that acquires inhibitory ITAM signaling properties (ITAMi) with low level of engagement through monomer or dimers, but activation properties only when fully cross linked (58-60). This pathway may thereby explain at least partly the inhibitory effect of high-dose Intravenous Immunoglobulin (IVIg) treatment in autoimmune diseases. But what would be the physiological relevance of this inhibitory mechanism, as most immune responses against invading pathogens result not only in either IgA or IgG responses, but both? Perhaps the solution is to be sought by the fact that some autoimmune responses seem to be mostly restricted to IgG, allowing for dampening of these unwanted responses. If true, it may also explain increased tendency of autoimmune diseases, for example in IgA deficiency (62).

\section{NEONATAL FC-RECEPTOR}

The neonatal Fc-receptor is responsible for the materno-fetal transplacental-transport of IgG (63), and the extension of the half-life of IgG and albumin (64). Originally, FcRn was described in rodents to transport IgG from mothers milk to the suckling neonates, providing them with humoral immunity after birth (65, 66). Later work utilizing electron tomography, has shown IgG to be taken up by FcRn-positive epithelial cells in the proximal small intestines, where it traverses the cell through entangled network of tubular structures, through multivesicular bodies, accumulating in basolateral intercellular spaces separated from the gut lumen by tight junctions $(67,68)$. Initiation of transport, takes place after binding of IgG and albumin by FcRn at low $\mathrm{pH}$, which results in the rescue of molecules from developing lysosomes. The receptor then transports its cargo to either the apical or basolateral surface, and releases it at neutral $\mathrm{pH}$, thereby accomplishing transcytosis or recycling. In this way, FcRn is apparently able to transport IgG 
effectively, even through stratified cell layers as for example in the placenta [reviewed in (69)], and perhaps also through walls of vaginal and oral cavities, although this has not been proven. However, the FcRn is not only expressed on epithelial and endothelial cells, but also at high levels on myeloid cells where it participates in phagocytosis of IgG-opsonized bacteria and immune complexuptake (70) and can enhance antigen presentation on dendritic cells (DCs) (71-77). It has also been reported to be responsible for bidirectional transport of IgG across epithelial layers and to play a vital role in delivery of IgG to the lumen of the gut, genital areas, and lung $(73,74,78)$ (Figure 1B). In this way, FcRn has for example been shown to bring protective immunity against helicobacter species (79). Inflammation caused by such infection, may affect FcRn expression, as FcRn is sensitive to NFкB-signaling. In accordance, FcRn expression is upregulated by TNF- $\alpha$, but also by the TLR ligands gram negative endotoxins (lipopolysaccharides) and CpG oligodeoxynucleotides (80). This may not only cause increase in the FcRn-saturation levels, causing increase in systemic IgG and albumin levels $(64,81)$, but also increased transport of locally and/or systematically produced IgG and albumin, and perhaps explain increased mucosal transport of IgG in pIgR KO mice that display increased IgG and albumin levels (82). The increased salivary IgG levels found for example in excessive Gingivitis cases, may therefore very well due to FcRn-upregulation, but it still need to be tested whether this is the case, as inflammation may also cause excessive leakiness of the epithelium (83).

In addition to IgG catabolism and transfer, the FcRn may mediate transport of IgG-antigen complexes from the basolateral surface back to the intestinal lumen. In this way FcRn has also been demonstrated to actively participate in the intracellular viral neutralization (84). Perhaps even more importantly, this transport is bidirectional as FcRn can mediate antigen sampling by transporting these IgG-antigen complexes from the lumen to regional lymphoid structures for amplification of immune responses (74) (Figure 3). The IgG response generated in this

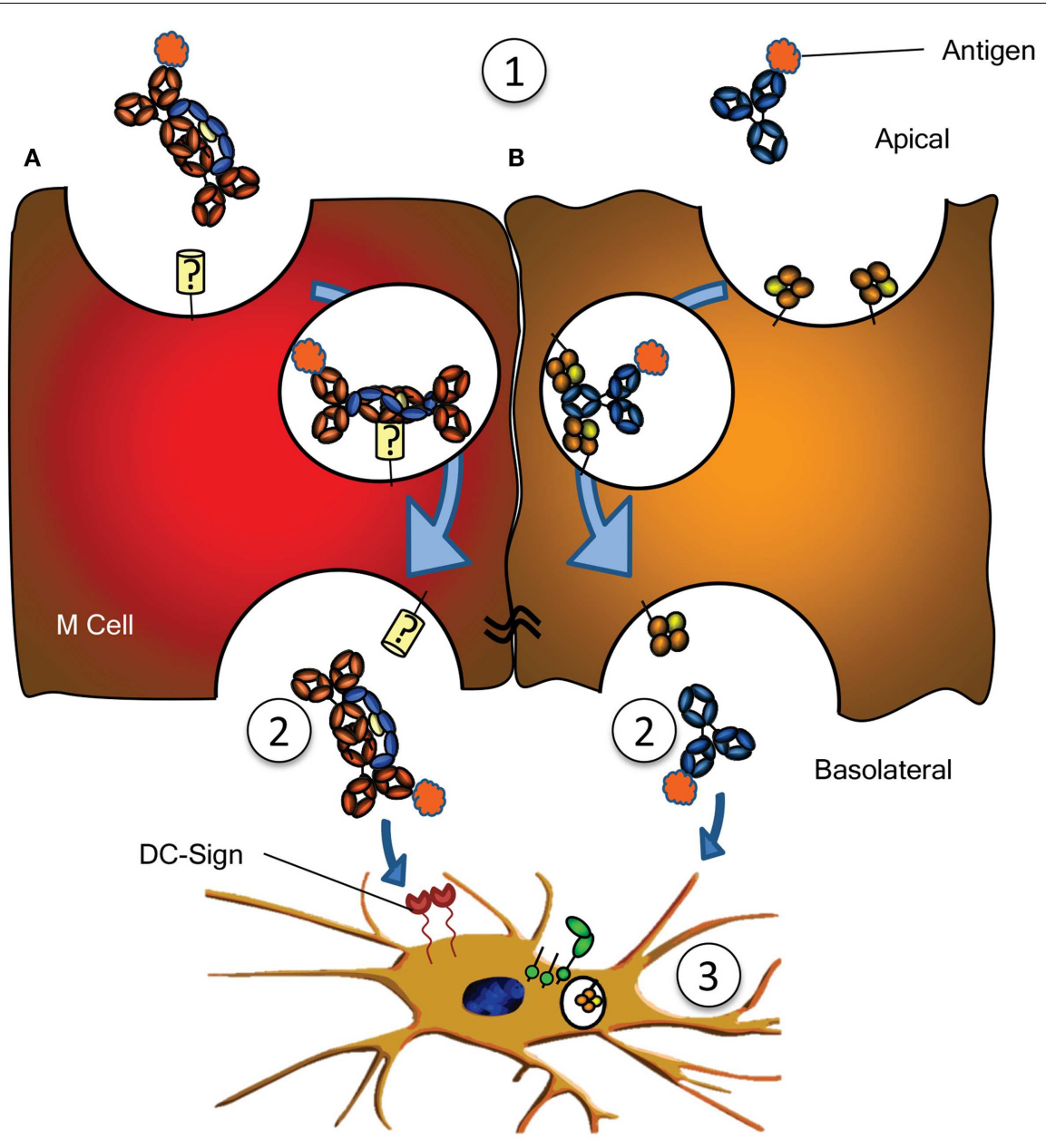

FIGURE 3 | Antigen sampling and amplification of humoral immune responses. (A) SIgA recognizing its cognate antigen (1) is taken up by $\mathrm{M}$ cell, possibly though a yet unidentified receptor on $\mathrm{M}$ cells. This complex has been demonstrated to traverse the epithelial layer (2) and to be taken up by DCs (3) possibly through DC-SIGN recognition. (B) Similarly, antigen bound by IgG (1) can traverse the epithelial layer through FcRn-depended transcytosis and taken up by DCs through Fc $\gamma R$ and FcRn (2) (73). Both IgG- or IgA-mediated antigen uptake can enhance antigen presentation, subsequent activation and proliferation of antigen-specific B- and T cells, boosting immune responses (3). See text for more details. 
way further stimulates secretion of immunoglobulin and its transport to the lumen where it actively mediates clearance and/or protection against pathogens, as recently shown for immunity against HIV and Citrobacter rodentium in a mouse models (74, $85,86)$. FcRn is therefore active at various levels in immunity; from half-life extension of IgG to transport of IgG to relevant sites, and together with classical $F c \gamma R$, directs pathogen eradication by phagocytosis and amplification of immune responses (70, $73-77,85)$.

In rodent models, FcRn also has a potentially important role in transmission of IgG from the breast milk of allergic mothers which has been shown to decrease the severity of allergic disease in the suckling offspring (87-89). This pathway is probably limited to species where materno-fetal transfer of IgG takes place through breastfeeding, and is thus not applicable to humans where IgG is almost exclusively transferred to the neonate before birth via the placenta. However, it is as of yet unknown if placentaltransport of IgG may affect sensitization of the newborn to allergens.

\section{LESS CHARACTERIZED Ig-RECEPTORS}

Numerous other receptors have been described to bind immunoglobulins (Table 1), but many need confirmation, while the function of many others is completely unknown. An example is the FceRII (CD23), which has been described to translocate IgE bilaterally through gut epithelial cells, capable of translocating IgE-bound allergens, perhaps explaining some aspects of food allergy, but also immunity against gut parasites $(90,91)$. One intriguing scenario is the possible role for SIgA in immune surveillance by the sampling of antigens from the lumen of the intestine. By transcytosis through M cells of the Peyer's patches on its own or in complex with antigen, IgA has been found to interact with sub-epithelial DCs. The receptor on $\mathrm{M}$ cells is hitherto unreported but interactions with DCs are believed to be mediated by DC-SIGN (Figure 3A) (92). Curiously, DC-SIGN has also recently been described to bind Fc-sialylated $\operatorname{IgG}(93,94)$, a subfraction of IgG, representing approximately $10 \%$ of all IgG. Although the interaction between sialylated IgG and DC-SIGN in this case was found to have immunomodulatory properties (given as IVIg in rodent models), up regulating the inhibitory Fc $\gamma$ RIIb in the myeloid compartment, the normal physiological role of this interaction between Ig and DC-SIGN is still completely unknown. Curiously, DC-SIGN is encoded in a cluster of related genes, which includes CD23, which, like DC-SIGN, is a type II trimeric membrane lectin. The $\mathrm{C}$ terminal domain of these proteins, in CD23 encoding for the binding domain for IgE - to which it binds through protein-protein interaction (95) - share $42 \%$ sequence homology, and are structurally highly conserved

\section{REFERENCES}

1. Gallo RL, Hooper LV. Epithelial antimicrobial defence of the skin and intestine. Nat Rev Immunol (2012) 12:503-16. doi:10.1038/nri3228

2. Belyakov IM, Ahlers JD. What role does the route of immunization play in the generation of protective immunity against mucosal pathogens? J Immunol (2009) 183:6883-92. doi:10.4049/ jimmunol.0901466

3. Kutteh WH, Prince SJ, Hammond KR, Kutteh CC, Mestecky J. Variations in immunoglobulins and IgA subclasses of

(structural alignment of DC-SIGN PDB ID 1K9J vs. CD23 PDB ID 4EZM). Furthermore, the location in where CD23 interacts with IgE, is highly homologous to $\mathrm{CH} 2 / \mathrm{CH} 3$ of the IgG-Fc, suggesting that DC-SIGN may perhaps also interact with IgG through protein-protein interactions (96), which would explain why a recent study found no indication of DC-SIGN interacting with glycan structures of IgG (97). An even more curious receptor, the Tripartite Motif-containing 21 (TRIM21) is expressed in the cytoplasm of most cells, particularly in immune cell, and recognizes at least both IgG and IgM $(98,99)$. The binding to IgG is of very high $\left(K_{\mathrm{d}}=37 \mathrm{nM}\right)$, requires the TRIM21 PRYSPRY motif, and binds IgG in the interface of $\mathrm{CH} 2$ and $\mathrm{CH} 3$, to a similar same interface as protein A/G and FcRn $(99,100)$. The peculiar cytoplasmic location of TRIM21 renders it physically incapable of interacting with immunoglobulin under normal circumstances. However, TRIM is apparently capable of recognizing opsonized viral targets after internalization and cytoplasmic translocation and inhibits their cytoplasmic replication by targeting them for ubiquitinationdependent destruction (99). Importantly, this would only target non-enveloped viral particles like noroviruses, rotaviruses, or human papilloma viruses, but not enveloped viruses, as these shed their opsonized envelopes on cytoplasmic entry. Recently, James and colleagues describe TRIM21 to recognize other isotypes as well, like IgM, and triggering a surge of proinflammatory cytokines, also in response to Ig-opsonized intracellular bacteria like Salmonella (101). It is unclear how the relative importance of this pathway in host-protect is, given that systemic elimination by other pathways (e.g., complement, Fc $\gamma$ R, and myeloid system). The current evidence therefore suggest TRIM21 to be particularly important at locations where complement and the myeloid system are less prominently present, e.g., at mucosal surfaces of the gut. The relative importance of this system compared to the other receptor systems for viral elimination awaits further confirmation.

\section{CONCLUSION}

Recent advances in knowledge of mucosal antibodies and novel receptor functions, provides a platform for work toward the induction of protective mucosal immune responses. Considerably further research into the precise mechanisms involved are required in order to understand how to elicit protective immune responses required for both systemic and mucosal protection, information that will also benefit passively administered immunoglobulin therapies.

\section{ACKNOWLEDGMENTS}

Rachel E. Horton was funded by a Griffith University New Researcher Grant: NLRD/75/09.

human uterine cervical secretions around the time of ovulation. Clin Exp Immunol (1996) 104:538-42. doi:10.1046/j.13652249.1996.36742.x

4. Moldoveanu Z, Huang WQ, Kulhavy R, Pate MS, Mestecky J. Human male genital tract secretions: both mucosal and systemic immune compartments contribute to the humoral immunity. J Immunol (2005) 175:4127-36.

5. Norderhaug IN, Johansen FE, Schjerven H, Brandtzaeg P. Regulation of the formation and external transport of secretory immunoglobulins. Crit Rev Immunol (1999) 19:481-508. 
6. Delacroix DL, Dive C, Rambaud JC, Vaerman JP. IgA subclasses in various secretions and in serum. Immunology (1982) 47: 383-5.

7. Mestecky J, Moro I, Kerr MA, Woof JM. Mucosal immunoglobulins. In: Mestecky J, Lamm ME, Strober W, Bienenstock J, McGhee J, Mayer L, editors. Mucosal Immunology. 3rd ed. Burlington, MA: Elsevier (1995). p. 153-82.

8. Chen $\mathrm{K}, \mathrm{Xu} \mathrm{W}$, Wilson $\mathrm{M}$, $\mathrm{He}$ B, Miller NW, Bengten $\mathrm{E}$, et al. Immunoglobulin D enhances immune surveillance by activating antimicrobial, proinflammatory and $B$ cell-stimulating programs in basophils. Nat Immunol (2009) 10:889-98. doi:10.1038/ni.1748

9. Persson CG, Erjefalt I, Gustafsson B, Luts A. Subepithelial hydrostatic pressure may regulate plasma exudation across the mucosa. Int Arch Allergy Appl Immunol (1990) 92:148-53. doi:10.1159/000235206

10. Van Itallie CM, Anderson JM. The molecular physiology of tight junction pores. Physiology (Bethesda) (2004) 19: 331-8. doi:10.1152/physiol. 00027.2004

11. Goodrich ME, McGee DW. Regulation of mucosal B cell immunoglobulin secretion by intestinal epithelial cell-derived cytokines. Cytokine (1998) 10:948-55. doi:10.1006/cyto.1998.0385

12. Bergqvist $\mathrm{P}$, Stensson A, Lycke NY, Bemark MT. Cellindependent IgA class switch recombination is restricted to the GALT and occurs prior to manifest germinal center formation. J Immunol (2010) 184:3545-53. doi:10.4049/ jimmunol.0901895

13. Berkowska MA, Driessen GJ, Bikos V, Grosserichter-Wagener C, Stamatopoulos K, Cerutti A, et al. Human memory B cells originate from three distinct germinal center-dependent and -independent maturation pathways. Blood (2011) 118:2150-8. doi:10.1182/blood-2011-04345579

14. Haraldsson A, Weemaes CM, Kock-Jansen MJ, Van Eck-Arts $\mathrm{PB}$, de Boo T, Bakkeren JA, et al. Immunoglobulin $G, A$ and $M$ light chain ratio in children. Ann Clin Biochem (1992) 29(Pt 3):271-4.
15. Kutteh WH, Prince SJ, Mestecky J. Tissue origins of human polymeric and monomeric IgA. J Immunol (1982) 128:990-5.

16. Russell MW, Sibley DA, Nikolova EB, Tomana M, Mestecky J. IgA antibody as a non-inflammatory regulator of immunity. Biochem Soc Trans (1997) 25:466-70.

17. Zhou D, Zhang Y, Li Q, Chen $\mathrm{Y}, \mathrm{He} \mathrm{B}$, Yang J, et al. Matrix protein-specific IgA antibody inhibits measles virus replication by intracellular neutralization. J Virol (2011) 85:11090-7. doi:10.1128/JVI.00768-11

18. Mazanec MB, Nedrud JG, Kaetzel CS, Lamm ME. A three-tiered view of the role of IgA in mucosal defense. Immunol Today (1993) 14:430-5. doi:10.1016/01675699(93)90245-G

19. Roos A, Bouwman LH, van Gijlswijk-Janssen DJ, Faber-Krol MC, Stahl GL, Daha MR. Human IgA activates the complement system via the mannan-binding lectin pathway. JImmunol (2001) 167:2861-8.

20. Takahashi K, Smith AD, Poulsen K, Kilian M, Julian BA, Mestecky $\mathrm{J}$, et al. Naturally occurring structural isomers in serum IgA1 O-glycosylation. J Proteome Res (2012) 11:692-702. doi:10.1021/pr200608q

21. Mestecky J, Russell MW. Specific antibody activity, glycan heterogeneity and polyreactivity contribute to the protective activity of S-IgA at mucosal surfaces. Immunol Lett (2009) 124:57-62. doi:10.1016/j.imlet.2009.03.013

22. Wuhrer M, Porcelijn L, Kapur R, Koeleman CA, Deelder A, de Haas M, et al. Regulated glycosylation patterns of $\mathrm{IgG}$ during alloimmune responses against human platelet antigens. J Proteome Res (2009) 8:450-6. doi:10.1021/pr800651j

23. Mathias A, Corthesy B. Recognition of gram-positive intestinal bacteria by hybridoma- and colostrum-derived secretory immunoglobulin A is mediated by carbohydrates. J Biol Chem (2011) 286:17239-47. doi:10.1074/jbc.M110.209015

24. Kaetzel CS, Robinson JK, Chintalacharuvu KR, Vaerman JP, Lamm ME. The polymeric immunoglobulin receptor (secretory component) mediates transport of immune complexes across epithelial cells: a local defense function for IgA. Proc Natl Acad Sci
U S A (1991) $\mathbf{8 8 : 8 7 9 6 - 8 0 0 . ~}$ doi:10.1073/pnas.88.19.8796

25. Natvig IB, Johansen FE, Nordeng TW, Haraldsen G, Brandtzaeg P. Mechanism for enhanced external transfer of dimeric IgA over pentameric IgM: studies of diffusion, binding to the human polymeric Ig receptor, and epithelial transcytosis. J Immunol (1997) 159:4330-40.

26. Kubagawa H, Oka S, Kubagawa Y, Torii I, Takayama E, Kang DW, et al. Identity of the elusive IgM Fc receptor (FcmuR) in humans. J Exp Med (2009) 206:2779-93. doi:10.1084/jem. 20091107

27. Lang KS, Lang PA, Meryk A, Pandyra AA, Boucher LM, Pozdeev VI, et al. Involvement of Toso in activation of monocytes, macrophages, and granulocytes. Proc Natl Acad Sci U S A (2013) 110:2593-8. doi:10.1073/pnas.1222264110

28. Brandtzaeg P, Gjeruldsen ST, Korsrud F, Baklien K, Berdal P, Ek J. The human secretory immune system shows striking heterogeneity with regard to involvement of J chain-positive IgD immunocytes. J Immunol (1979) 122:503-10.

29. Brandtzaeg P, Farstad IN, Johansen FE, Morton HC, Norderhaug IN, Yamanaka T. The B-cell system of human mucosae and exocrine glands. Immunol Rev (1999) 171:45-87. doi:10.1111/j.1600065X.1999.tb01342.x

30. Brandtzaeg P. Potential of nasopharynx-associated lymphoid tissue for vaccine responses in the airways. Am J Respir Crit Care Med (2011) 183:1595-604. doi:10.1164/rccm.201011$1783 \mathrm{OC}$

31. Finkelman FD, van Boxel JA, Asofsky R, Paul WE. Cell membrane IgD: demonstration of IgD on human lymphocytes by enzyme-catalyzed iodination and comparison with cell surface Ig of mouse, guinea pig, and rabbit. J Immunol (1976) 116:1173-81.

32. Chen K, Cerutti A. The function and regulation of immunoglobulin D. Curr Opin Immunol (2011) 23:345-52. doi:10.1016/j.coi.2011.01.006

33. Stapleton NM, Andersen JT, Stemerding AM, Bjarnarson SP, Verheul RC, Gerritsen J, et al. Competition for FcRn-mediated transport gives rise to short half-life of human IgG3 and offers therapeutic potential. Nat Commun (2011) 2:599. doi:10.1038/ncomms1608

34. Mascola JR, Stiegler G, VanCott TC, Katinger H, Carpenter CB, Hanson CE, et al. Protection of macaques against vaginal transmission of a pathogenic HIV-1/SIV chimeric virus by passive infusion of neutralizing antibodies. Nat Med (2000) 6:207-10. doi:10.1038/ 72318

35. Saeland E, Vidarsson G, Leusen JH, Van Garderen E, Nahm MH, Vile-Weekhout $\mathrm{H}$, et al. Central role of complement in passive protection by human IgG1 and IgG2 anti-pneumococcal antibodies in mice. J Immunol (2003) 170:6158-64.

36. Westerman LE, McClure HM, Jiang B, Almond JW, Glass RI. Serum IgG mediates mucosal immunity against rotavirus infection. Proc Natl Acad Sci U S A (2005) 102:7268-73. doi:10.1073/pnas.0502437102

37. Brandtzaeg P. Mucosal immunity in the female genital tract. $J$ Reprod Immunol (1997) 36:23-50. doi:10.1016/S01650378(97)00061-2

38. Gessner JE, Heiken H, Tamm A, Schmidt RE. The IgG Fc receptor family. Ann Hematol (1998) 76:231-48. doi:10.1007/s002770050396

39. Kaneko Y, Nimmerjahn F, Ravetch JV. Anti-inflammatory activity of immunoglobulin $\mathrm{G}$ resulting from $\mathrm{Fc}$ sialylation. Science (2006) 313:670-3. doi:10.1126/science.1129594

40. Niwa R, Natsume A, Uehara A, Wakitani M, Iida S, Uchida $\mathrm{K}$, et al. IgG subclassindependent improvement of antibody-dependent cellular cytotoxicity by fucose removal from Asn297-linked oligosaccharides. J Immunol Methods (2005) 306:151-60. doi:10.1016/j.jim.2005.08.009

41. Einarsdottir H, Ji Y, Visser G, Mo C, Luo G, Scherjon S, et al. H435containing IgG3 allotypes are transported efficiently across the human placenta: implications for alloantibody mediated diseases of the newborn. Transfusion (2013). doi:10.1111/trf.12334. [Epub ahead of print].

42. Simister NE. Placental transport of immunoglobulin G. Vaccine (2003) 
21:3365-9. doi:10.1016/S0264410X(03)00334-7

43. Raux M, Finkielsztejn L, SalmonCeron D, Bouchez H, Excler JL, Dulioust E, et al. IgG subclass distribution in serum and various mucosal fluids of HIV type 1infected subjects. AIDS Res Hum Retroviruses (2000) 16:583-94. doi:10.1089/088922200309007

44. Malek A, Sager R, Kuhn P, Nicolaides KH, Schneider H. Evolution of maternofetal transport of immunoglobulins during human pregnancy. Am J Reprod Immunol (1996) 36:248-55. doi:10.1111/j.16000897.1996.tb00172.x

45. Brandtzaeg P. Human secretory immunoglobulin M. An immunochemical and immunohistochemical study. Immunology (1975) 29:559-70.

46. Almogren A, Bonner A, Perkins SJ, Kerr MA. Functional and structural characterisation of human colostrum free secretory component. Mol Immunol (2009) 46:1534-41. doi:10. 1016/j.molimm.2008.12.022

47. Hayashi M, Takenouchi N, Asano M, Kato M, Tsurumachi T, Saito $\mathrm{T}$, et al. The polymeric immunoglobulin receptor (secretory component) in a human intestinal epithelial cell line is up-regulated by interleukin1. Immunology (1997) 92:220-5. doi:10.1046/j.13652567.1997.00341.x

48. Sollid LM, Kvale D, Brandtzaeg P, Markussen G, Thorsby E. Interferon-gamma enhances expression of secretory component, the epithelial receptor for polymeric immunoglobulins. $J$ Immunol (1987) 138:4303-6.

49. Jaffar Z, Ferrini ME, Girtsman TA, Roberts K. Antigen-specific Treg regulate Th17-mediated lung neutrophilic inflammation, B-cell recruitment and polymeric IgA and $\operatorname{IgM}$ levels in the airways. Eur $J$ Immunol (2009) 39:3307-14. doi:10.1002/eji.200939498

50. Morton HC, van Egmond $M$, van de Winkel JGJ. Structure and function of human IgA Fc receptors (Fc alpha R). Crit Rev Immunol (1996) 16:423-40.

51. Bakema JE, de Haij S, den Hartog-Jager CF, Bakker J, Vidarsson G, van Egmond M, et al. Signaling through mutants of the IgA receptor CD89 and consequences for $\mathrm{Fc}$ receptor gamma-chain interaction. $J$ Immunol (2006) 176:3603-10.

52. Bakema JE, Bakker A, de Haij S, Honing H, Bracke M, Koenderman L, et al. Inside-out regulation of Fc alpha RI (CD89) depends on PP2A. I Immunol (2008) 181:4080-8.

53. van Egmond $\mathrm{M}$, Damen $\mathrm{CA}$, van Spriel $A B$, Vidarsson G, van Garderen E, van de Winkel JG. IgA and the IgA Fc receptor. Trends Immunol (2001) 22:205-11. doi:10.1016/S14714906(01)01873-7

54. Vidarsson G, van Der Pol WL, van Den Elsen JM, Vile H, Jansen M, Duijs J, et al. Activity of human IgG and IgA subclasses in immune defense against Neisseria meningitidis serogroup B. J Immunol (2001) 166: 6250-6.

55. Herr AB, Ballister ER, Bjorkman PJ. Insights into IgA-mediated immune responses from the crystal structures of human FcalphaRI and its complex with IgA1-Fc. Nature (2003) 423:61420. doi:10.1038/nature01685

56. Nimmerjahn F, Ravetch JV. Antibody-mediated modulation of immune responses. Immunol Rev (2010) 236:265-75. doi:10.1111/j.1600065X.2010.00910.x

57. Bruhns $P$, Iannascoli B, England P, Mancardi DA, Fernandez N, Jorieux S, et al. Specificity and affinity of human Fcgamma receptors and their polymorphic variants for human IgG subclasses. Blood (2009) 113:371625. doi:10.1182/blood-2008-09179754

58. Pasquier B, Launay P, Kanamaru Y, Moura IC, Pfirsch S, Ruffie $C$, et al. Identification of FcalphaRI as an inhibitory receptor that controls inflammation: dual role of FcRgamma ITAM. Immunity (2005) 22:3142. doi:10.1016/j.immuni.2004. 11.017

59. Pfirsch-Maisonnas S, Aloulou $\mathrm{M}, \mathrm{Xu} \mathrm{T}$, Claver J, Kanamaru $\mathrm{Y}$, Tiwari $\mathrm{M}$, et al. Inhibitory ITAM signaling traps activating receptors with the phosphatase SHP-1 to form polarized "inhibisome" clusters. Sci Signal (2011) 4:ra24. doi:10.1126/scisignal.2001309

60. Aloulou M, Ben Mkaddem S, Biarnes-Pelicot M, Boussetta T, Souchet H, Rossato E, et al. IgG1 and IVIg induce inhibitory ITAM signaling through FcgammaRIII controlling inflammatory responses. Blood (2012) 119:3084-96. doi:10.1182/ blood-2011-08-376046

61. Jang JE, Hidalgo A, Frenette PS Intravenous immunoglobulins modulate neutrophil activation and vascular injury through FcgammaRIII and SHP-1. Circ Res (2012) 110:1057-66. doi:10.1161/CIRCRESAHA.112. 266411

62. Wang $N$, Shen $N$, Vyse TJ, Anand V, Gunnarson I, Sturfelt $G$, et al. Selective IgA deficiency in autoimmune diseases. Mol Med (2011) 17:1383-96. doi:10.2119/molmed.2011.00195

63. Simister NE, Story CM, Chen HL, Hunt JS. An IgGtransporting $\mathrm{Fc}$ receptor expressed in the syncytiotrophoblast of human placenta. Eur J Immunol (1996) 26:1527-31. doi:10.1002/eji.1830260718

64. Chaudhury C, Mehnaz S, Robinson JM, Hayton WL, Pearl DK, Roopenian DC, et al. The major histocompatibility complex-related $\mathrm{Fc}$ receptor for $\operatorname{IgG}(\mathrm{FcRn})$ binds albumin and prolongs its lifespan. $J$ Exp Med (2003) 197:315-22. doi:10.1084/jem.20021829

65. Simister NE, Mostov KE. An Fc receptor structurally related to MHC class I antigens. Nature (1989) 337:184-7. doi:10.1038/337184a0

66. Kim J, Mohanty S, Ganesan LP, Hua K, Jarjoura D, Hayton WL, et al. FcRn in the yolk sac endoderm of mouse is required for IgG transport to fetus. J Immunol (2009) 182:2583-9. doi:10.4049/jimmunol.0803247

67. He W, Ladinsky MS, HueyTubman KE, Jensen GJ, McIntosh JR, Bjorkman PJ. FcRn-mediated antibody transport across epithelial cells revealed by electron tomography. Nature (2008) 455:542-6. doi:10.1038/nature07255

68. Ladinsky MS, Huey-Tubman KE, Bjorkman PJ. Electron tomography of late stages of FcRnmediated antibody transcytosis in neonatal rat small intestine. Mol Biol Cell (2012) 23:2537-45. doi:10.1091/mbc.E12-02-0093

69. Sesarman A, Vidarsson G, Sitaru C. The neonatal Fc receptor as therapeutic target in IgG-mediated autoimmune diseases. Cell Mol Life Sci (2010) 67:2533-50. doi:10.1007/s00018-010-0318-6
70. Vidarsson G, Stemerding AM, Stapleton NM, Spliethoff SE, Janssen H, Rebers FE, et al. FcRn: an IgG receptor on phagocytes with a novel role in phagocytosis. Blood (2006) 108:3573-9. doi:10.1182/blood2006-05-024539

71. Mi W, Wanjie S, Lo ST, Gan Z, Pickl-Herk B, Ober RJ, et al. Targeting the neonatal $\mathrm{fc}$ receptor for antigen delivery using engineered fc fragments. J Immunol (2008) 181:7550-61.

72. Qiao SW, Kobayashi K, Johansen FE, Sollid LM, Andersen JT, Milford E, et al. Dependence of antibody-mediated presentation of antigen on FcRn. Proc Natl Acad Sci U S A (2008) 105: 9337-42. doi:10.1073/pnas.080 1717105

73. Yoshida M, Claypool SM, Wagner JS, Mizoguchi E, Mizoguchi A, Roopenian DC, et al. Human neonatal Fc receptor mediates transport of IgG into luminal secretions for delivery of antigens to mucosal dendritic cells. Immunity (2004) 20:769-83. doi:10.1016/ j.immuni.2004.05.007

74. Yoshida M, Kobayashi K, Kuo TT, Bry L, Glickman JN, Claypool SM, et al. Neonatal Fc receptor for IgG regulates mucosal immune responses to luminal bacteria. $J$ Clin Invest (2006) 116:2142-51. doi:10.1172/JCI27821

75. Catunda Lemos AP, Cervenak J, Bender B, Hoffmann OI, Baranyi M, Kerekes A, et al. Characterization of the rabbit neonatal $\mathrm{Fc}$ receptor $(\mathrm{FcRn})$ and analyzing the immunophenotype of the transgenic rabbits that overexpresses FcRn. PLoS ONE (2012) 7:e28869. doi:10.1371/journal.pone.002 8869

76. Cervenak J, Bender B, Schneider Z, Magna M, Carstea BV, Liliom $\mathrm{K}$, et al. Neonatal FcR overexpression boosts humoral immune response in transgenic mice. J Immunol (2011) 186:959-68. doi:10.4049/jimmunol.1000353

77. Vegh A, Farkas A, Kovesdi D, Papp K, Cervenak J, Schneider $Z$, et al. FcRn overexpression in transgenic mice results in augmented APC activity and robust immune response with increased diversity of induced antibodies. PLOS ONE (2012) 7:e36286. doi:10.1371/ journal.pone.0036286 
78. Bitonti AJ, Dumont JA, Low SC, Peters RT, Kropp KE, Palombella VJ, et al. Pulmonary delivery of an erythropoietin Fc fusion protein in non-human primates through an immunoglobulin transport pathway. Proc Natl Acad Sci U S A (2004) 101:9763-8. doi:10.1073/ pnas.0403235101

79. Ben Suleiman Y, Yoshida M, Nishiumi S, Tanaka H, Mimura T, Nobutani $\mathrm{K}$, et al. Neonatal Fc receptor for IgG $(\mathrm{FcRn})$ expressed in the gastric epithelium regulates bacterial infection in mice. Mucosal Immunol (2012) 5:87-98. doi:10.1038/mi.2011.53

80. Liu X, Ye L, Christianson GJ, Yang JQ, Roopenian DC, Zhu X. NFkappaB signaling regulates functional expression of the MHC class I-related neonatal Fc receptor for IgG via intronic binding sequences. J Immunol (2007) 179:2999-3011.

81. Junghans RP. IgG biosynthesis: no "immunoregulatory feedback”. Blood (1997) 90:3815-8.

82. Johansen FE, Pekna M, Norderhaug IN, Haneberg B, Hietala MA, Krajci P, et al. Absence of epithelial immunoglobulin A transport, with increased mucosal leakiness, in polymeric immunoglobulin receptor/secretory component-deficient mice. $J$ Exp Med (1999) 190:915-22. doi:10.1084/jem.190.7.915

83. Brandtzaeg P. Secretory immunity with special reference to the oral cavity. J Oral Microbiol (2013) 5:20401. doi:10.3402/jom.v5i0.20401

84. Bai Y, Ye L, Tesar DB, Song $\mathrm{H}$, Zhao D, Bjorkman PJ, et al. Intracellular neutralization of viral infection in polarized epithelial cells by neonatal Fc receptor (FcRn)mediated IgG transport. Proc Natl Acad Sci U S A (2011) 108: 18406-11. doi:10.1073/pnas. 1115348108

85. Lu L, Palaniyandi S, Zeng R, Bai Y, Liu X, Wang Y, et al. A neonatal Fc receptor-targeted mucosal vaccine strategy effectively induces HIV-1 antigen-specific immunity to genital infection. J Virol (2011) 85:10542-53. doi:10.1128/JVI.05441-11

86. Li Z, Palaniyandi S, Zeng R, Tuo W, Roopenian DC, Zhu X. Transfer of $\mathrm{IgG}$ in the female genital tract by MHC class
I-related neonatal Fc receptor (FcRn) confers protective immunity to vaginal infection. Proc Natl Acad Sci U S A (2011) 108:4388-93. doi:10.1073/pnas. 1012861108

87. Matson AP, Thrall RS, Rafti E, Lingenheld EG, Puddington L. IgG transmitted from allergic mothers decreases allergic sensitization in breastfed offspring. Clin Mol Allergy (2010) 8:9. doi:10.1186/1476-7961-8-9

88. Nakata K, Kobayashi K, Ishikawa Y, Yamamoto M, Funada Y, Kotani Y, et al. The transfer of maternal antigen-specific IgG regulates the development of allergic airway inflammation early in life in an FcRn-dependent manner. Biochem Biophys Res Commun (2010) 395:238-43. doi:10.1016/j.bbrc.2010.03.170

89. Polte T, Hansen G. Maternal tolerance achieved during pregnancy is transferred to the offspring via breast milk and persistently protects the offspring from allergic asthma. Clin Exp Allergy (2008) 38:1950-8. doi:10.1111/j.13652222.2008.03096.X

90. Tu Y, Perdue MH. CD23mediated transport of IgE/immune complexes across human intestinal epithelium: role of p38 MAPK. Am J Physiol Gastrointest Liver Physiol (2006) 291:G532-8. doi:10.1152/ajpgi.00524.2005

91. Yang PC, Berin MC, Yu LC, Conrad DH, Perdue MH. Enhanced intestinal transepithelial antigen transport in allergic rats is mediated by IgE and CD23 (FcepsilonRII). J Clin Invest (2000) 106:879-86. doi:10.1172/JCI9258

92. Baumann J, Park CG, Mantis NJ. Recognition of secretory IgA by DC-SIGN: implications for immune surveillance in the intestine. Immunol Lett (2010) 131:59-66. doi:10.1016/j.imlet.2010.03.005

93. Anthony RM, Kobayashi T, Wermeling F, Ravetch JV. Intravenous gammaglobulin suppresses inflammation through a novel $\mathrm{T}(\mathrm{H}) 2$ pathway. Nature (2011) 475:110-3. doi:10.1038/nature 10134

94. Anthony RM, Wermeling F, Karlsson MC, Ravetch JV. Identification of a receptor required for the anti-inflammatory activity of IVIG. Proc Natl Acad
Sci U S A (2008) 105:19571-8. doi:10.1073/pnas.0810163105

95. Dhaliwal B, Yuan D, Pang MO, Henry AJ, Cain K, Oxbrow $A$, et al. Crystal structure of $\operatorname{IgE}$ bound to its B-cell receptor $\mathrm{CD} 23$ reveals a mechanism of reciprocal allosteric inhibition with high affinity receptor FcepsilonRI. Proc Natl Acad Sci U S A (2012) 109: 12686-91. doi:10.1073/pnas.1207278109

96. Sondermann P, Pincetic A, Maamary J, Lammens K, Ravetch JV. General mechanism for modulating immunoglobulin effector function. Proc Natl Acad Sci U S A (2013) 110: 9868-72. doi:10.1073/pnas. 1307864110

97. Yu X, Vasiljevic S, Mitchell DA, Crispin M, Scanlan CN. Dissecting the molecular mechanism of IVIg therapy: the interaction between serum IgG and DCSIGN is independent of antibody glycoform or $\mathrm{Fc}$ domain. J Mol Biol (2013) 425:1253-8. doi:10.1016/j.jmb

98. Hauler F, Mallery DL, McEwan WA, Bidgood SR, James LC. AAA ATPase p97/VCP is essential for TRIM21-mediated virus neutralization. Proc Natl Acad Sci U S A (2012) 109:19733-8. doi:10.1073/ pnas. 1210659109

99. Mallery DL, McEwan WA Bidgood SR, Towers GJ, Johnson CM, James LC. Antibodies mediate intracellular immunity through tripartite motifcontaining 21 (TRIM21). Proc Natl Acad Sci U S A (2010) 107: 19985-90. doi:10.1073/pnas. 1014074107

100. James LC, Keeble AH, Khan Z, Rhodes DA, Trowsdale J. Structural basis for PRYSPRY-mediated tripartite motif (TRIM) protein function. Proc Natl Acad Sci U S A (2007) 104:6200-5. doi:10.1073/pnas.0609174104

101. McEwan WA, Tam JC, Watkinson RE, Bidgood SR, Mallery DL, James LC. Intracellular antibody-bound pathogens stimulate immune signaling via the Fc receptor TRIM21. Nat Immunol (2013) 14:327-36. doi:10.1038/ni.2548

102. Brandtzaeg P, Prydz H. Direct evidence for an integrated function of $\mathrm{J}$ chain and secretory component in epithelial transport of immunoglobulins.
Nature (1984) 311:71-3 doi:10.1038/311071a0

103. Albrechtsen M, Yeaman GR, Kerr MA. Characterization of the IgA receptor from human polymorphonuclear leucocytes. Immunology (1988) 64: 201-5.

104. Shibuya A, Sakamoto N, Shimizu Y, Shibuya K, Osawa M, Hiroyama T, et al. Fc alpha/mu receptor mediates endocytosis of IgM-coated microbes. Nat Immunol (2000) 1:441-6. doi:10.1038/80886

105. Tomana M, Zikan J, Moldoveanu Z, Kulhavy R, Bennett JC, Mestecky J. Interactions of cell-surface galactosyltransferase with immunoglobulins. Mol Immunol (1993) 30:265-75. doi:10.1016/01615890(93)90055-G

106. Moura IC, Centelles MN, Arcos-Fajardo M, Malheiros DM, Collawn JF, Cooper $\mathrm{MD}$, et al. Identification of the transferrin receptor as a novel immunoglobulin (Ig)A1 receptor and its enhanced expression on mesangial cells in IgA nephropathy. $J$ Exp Med (2001) 194:417-25. doi:10.1084/ jem.194.4.417

107. Lamkhioued B, Gounni AS, Gruart V, Pierce A, Capron A, Capron M. Human eosinophils express a receptor for secretory component. Role in secretory IgA-dependent activation. Eur J Immunol (1995) 25 117-25.

doi:10.1002/eji.1830250121

108. Motegi Y, Kita H. Interaction with secretory component stimulates effector functions of human eosinophils but not of neutrophils. J Immunol (1998) 161:4340-6.

109. Stockert RJ, Kressner MS, Collins JC, Sternlieb I, Morell AG. IgA interaction with the asialoglycoprotein receptor. Proc Natl Acad Sci U S A (1982) 79:6229-31. doi:10.1073/ pnas.79.20.6229

110. Bournazos S, Woof JM, Hart SP, Dransfield I. Functional and clinical consequences of $\mathrm{Fc}$ receptor polymorphic and copy number variants. Clin Exp Immunol (2009) 157:244-54. doi:10.1111/j.13652249.2009.03980.x

111. Ravetch JV, Bolland S. IgG Fc receptors. Annu Rev Immunol (2001) 19:275-90. doi:10. 1146/annurev.immunol.19.1.275 
112. Wilson TJ, Fuchs A, Colonna M. Cutting edge: human FcRL4 and FcRL5 are receptors for IgA and IgG. J Immunol (2012) 188: 4741-5. doi:10.4049/jimmunol. 1102651

113. Israel EJ, Taylor $\mathrm{S}$, Wu Z, Mizoguchi E, Blumberg RS, Bhan A, et al. Expression of the neonatal Fc receptor, FcRn, on human intestinal epithelial cells. Immunology (1997) 92:69-74. doi:10.1046/j.1365-2567.1997. 00326.x
114. Preud'homme JL, Petit I, Barra A, Morel F, Lecron JC, Lelievre E. Structural and functional properties of membrane and secreted IgD. Mol Immunol (2000) 37:871-87. doi:10.1016/S01615890(01)00006-2

115. Ramsland PA, Farrugia W, Bradford TM, Sardjono CT, Esparon S, Trist HM, et al. Structural basis for Fc $\gamma$ RIIa recognition of human $\operatorname{IgG}$ and formation of inflammatory signaling
Immunol (2011) 187:3208-17. doi:10.4049/jimmunol.1101467

Conflict of Interest Statement: The authors declare that the research was conducted in the absence of any commercial or financial relationships that could be construed as a potential conflict of interest.

Received: 10 April 2013; accepted: 03 July 2013; published online: 16 July 2013.

Citation: Horton RE and Vidarsson $G$ (2013) Antibodies and their receptors: different potential roles in mucosal defense. Front. Immunol. 4:200. doi: 10.3389/fimmu.2013.00200

This article was submitted to Frontiers in Mucosal Immunity, a specialty of Frontiers in Immunology.

Copyright $\odot 2013$ Horton and Vidarsson. This is an open-access article distributed under the terms of the Creative Commons Attribution License, which permits use, distribution and reproduction in other forums, provided the original authors and source are credited and subject to any copyright notices concerning any third-party graphics etc. 